\title{
Profil Perilaku Altruistik Mahasiswa dan Implikasinya terhadap Program Pelatihan Kompetensi Kepribadian Calon Konselor
}

\author{
Rina Yulitri ${ }^{1}$, Ardimen $^{2}$, Emeliya Hardi ${ }^{3}$, Gustina ${ }^{4}$ \\ Jurusan BK FTIK IAIN Batusangkar ${ }^{1,2, ~ \& ~} 3$, Jurusan PAI FTIK IAIN Batusangkar ${ }^{4}$ \\ Email: rinayulitri@iainbatusangkar.ac.id ${ }^{1}$, ardimen@iainbatusangkar.ac.id ${ }^{2}$, \\ emeliyahardi@iainbatusangkar.ac.id ${ }^{3}$, gustina@iainbatusangkar.ac.id ${ }^{4}$
}

\begin{abstract}
:
The purpose of this study is to describe the altruistic behavior of student guidance and counseling. This type of research is quantitative descriptive. The study population was students majoring in guidance and counseling at IAIN Batusangkar. Sampling with a purposive sampling technique, namely 74 semester 7 students. Data analysis was performed by univariate analysis which produced a frequency distribution based on the percentage of each indicator characteristic studied. The results of this study indicate that only a small proportion of students have altruistic behavior at high and very high classifications. While altruistic behavior in aspects of wanting to give, empathy, volunteering, helping others, prioritizing others, and feeling the results are good for those who are helped and helped are in the medium classification.
\end{abstract}

Keyword: altruistic behavior, personality, prospective counselor

Received February 10, 2020; Revised March 7, 2020; Accepted April 1, 2020

How to Cite: Yulitri R., Ardimen, Hardi E., \& Gustina (2020). Profil Perilaku Altruistik Mahasiswa dan Implikasinya terhadap Program Pelatihan Kompetensi Kepribadian Calon Konselor JKI (Jurnal Konseling Indonesia), 5(2), 39-46.

This is an open access article distributed under the Creative Commons 4.0 Attribution License, which permits unrestricted use, distribution, and reproduction in any medium, provided the original work is properly cited. @2020 by author and Guidance and Counseling Program of Faculty of Education Sciences Universitas Kanjuruhan Malang.

\section{PENDAHULUAN}

Mahasiswa bimbingan dan konseling adalah individu-individu yang dipersiapkan secara akademik untuk menjadi guru BK atau konselor profesional. Konselor profesional memiliki beberapa kompetensi dan kemampuan dasar untuk melaksanakan layanan konseling secara efektif, salah satunya adalah kompetensi kepribadian. Menurut (Pane, 2016) kompetensi kepribadian konselor merupakan driving center keberhasilan layanan bimbingan dan konseling. Dengan demikian, kompetensi kepribadian konselor merupakan salah satu kompetensi yang mempunyai pengaruh signifikan dalam menentukan keberhasilan layanan konseling. Kepribadian konselor adalah suatu hal yang sangat penting dalam konseling. Seorang konselor haruslah dewasa, ramah, dan bisa berempati. Mereka harus altruistik (peduli pada kepentingan orang lain) (Ardimen, 2018b:102). (A. Putri, 2016) menegaskan bahwa keberhasilan konseling lebih tergantung pada kualitas pribadi konselor dibandingkan kecermatan teknik. Pribadi konselor yang amat penting mendukung efektivitas perannya adalah pribadi yang altuistik (rela berkorban/ suka menolong) untuk kepentingan konseli (A. Putri, 2016);(Sa'idah \& Annajih, 2019). Di samping itu, perilaku altruisme tersebut sangatlah dibutuhkan oleh para siswa agar mampu 
menjadi pribadi yang bertanggung jawab dalam kehidupan di lingkungan sekitarnya (Mesa, Aspin, \& Rudin, 2020). Oleh sebab itu, mahasiswa bimbingan dan konseling (BK) sebagai calon konselor sejatinya harus mengembangkan kualitas pribadi yang altruistik. Artinya, altruistik atau juga dikenal dengan perilaku altruistik wajib dimiliki oleh mahasiswa BK agar bisa menjadi konselor yang handal dan profesional sesuai dengan harapan siswa.

Konselor adalah tenaga pendidik profesional untuk membantu konseli memfasilitasi perkembangan optimal sesuai dengan tugas-tugas perkembangan konseli. Oleh karena itu, menjadi seorang konselor berarti memiliki perilaku altruistik agar proses pemberian bantuan berjalan dengan efektif dan maksimal untuk mencapai tujuan layanan. Hal tersebut diperkuat oleh (Yandri, Fikri, \& Juliawati, 2019) yang menyatakan bahwa pribadi konselor yang efektif harus dilandasi motif altruistik dimana seorang konselor memiliki kepedulian dan lebih mendahulukan kepentingan orang lain (klien) diatas kepentingan pribadinya. Perilaku altruisme adalah tindakan yang dilakukan oleh individu atau sekumpulan orang untuk melakukan kebaikan tanpa mengharap imbalan (Pamungkas \& Muslikah, 2019).

Tolong menolong merupakan suatu sikap alamiah yang terjadi pada setiap individu. Sebagai makhluk sosial tentunya setiap individu memiliki kebutuhan dasar untuk meminta dan memberikan pertolongan kepada orang lain. Bagi agama Islam, perilaku menolong merupakan perilaku yang sangat mulia dan sangat dihargai, sehingga setiap muslim wajib melakukannya. Dalam Al-Qur'an surat Al Maidah ayat 2, Allah SWT berfirman "dan tolong menolonglah kamu dalam (mngerjakan) kebajikan dan takwa, dan jangan tolong menolong dalam berbuat dosa dan pelanggaran. Dan bertakwalah kamu kepada Allah, sesungguhnya Allah amat berat siksaNya." Dari penjelasan ayat tersebut jelas bahwasanya Islam mengajarkan setiap muslim untuk saling tolong menolong dalam kebaikan, dapat memberikan manfaat yang baik bagi orang lain, meringankan beban orang lain, memberikan bantuan kepada mereka yang mengalami kesulitan tanpa mengharapkan adanya imbalan atas perbuatan yang dilakukannya. Sebaik-baiknya manusia adalah yang bisa memberikan manfaat untuk orang lain. Bahkan Allah berjanji akan meringanan penderitaan seseorang di dunia dan di akhirat jika mereka bisa meringankan penderitaan orang lain. Hal ini sesuai dengan hadis Nabi SAW yang berbunyi: Barang siapa melapangkan seorang mukmin dari suatu kesusahan dunia, Allah akan melapangkannya dari salah satu kesusahan di hari kiamat. Barang siapa meringankan penderitaan seseorang, Allah akan meringankan penderitaanya di dunia dan akhirat. Barang siapa menutupi (aib) seorang Muslim, Allah akan menutupi (aib)nya di dunia dan akhirat. Allah akan menolong seorang hamba selama hamba itu mau menolong saudaranya (HR. Muslim dari Abu Hurairah).

Perilaku Altruistik adalah tindakan sukarela yang dilakukan oleh seseorang untuk menolong orang lain tanpa mengharapkan imbalan apa pun (Diyai, Bidjuni, \& Onibala, 2019). Orang yang mempunyai kecenderungan memiliki perilaku altruisme memiliki ciri-ciri; (1) memberi pertolongan kepada orang lain dengan dimotivasi rasa empati, (2) sukarela, yaitu tidak karena ingin mendapatkan imbalan, dan (3) keinginan untuk memberi bantuan kepada orang lain yang membutuhkan meskipun tidak ada orang yang mengetahuinya Myears (Ni'mah, 2017).

Urgensi bimbingan dan konseling sebagai sebuah hubungan yang bersifat membantu membutuhkan seorang konselor yang memiliki perilaku altruistik yang baik. Hal ini dikarenakan jika konselor tidak memiliki perilaku altruistik maka ia akan kesulitan dalam membangun hubungan membantu dengan klien saat proses konseling berlangsung. Oleh sebab itu, dapat dikatakan bahwa seorang konselor "wajib" memiliki sikap dan tingkah laku altruistik. Kewajiban ini juga berlaku untuk orang-orang yang sedang mempersiapkan diri menjadi seorang konselor, yaitu mahasiswa BK mengingat perilaku altruistik bukanlah perilaku instan "sim salabim" yang langsung ada tanpa kemauan yang dibiasakan dan terus dilatihkan. Berkenaan dengan itu, maka penlitian untuk mengungkap profil perilaku altruistik mahasiswa BK sangat diperlukan adanya. Data tersebut dijadikan sebagai dasar analisis kebutuhan pengembangan program pelatihan kompetensi kepribadian calon konselor. Ada dua pertanyaan yang perlu dijawab melalui penelitian ini, yaitu bagaimanakah profil perilaku altruistik mahasiswa BK dan bagaimana desain hipotetik program pelatihan peningkatan kompetensi kepribadian calon konselor.

\section{METODE PENELITIAN}

Penelitian ini menggunakan jenis penelitian lapangan (field research) yang bersifat deskriptif kuantitatif. Populasi dalam penelitian ini adalah mahasiswa Bimbingan dan Konseling di IAIN Batusangkar yang aktif pada tahun ajaran 2018/2019 dan berjumlah 487 orang (Data Kemahasiswaan, 2018). Untuk mewakili populasi, peneliti mengambil sampel dengan teknik Purpossive sampling, yaitu mahasiswa semester 7 yang berjumlah 74 orang. Alasan penentuan sampel ini karena semester 7 adalah tahap akhir perkuliahan tatap muka. Mahasiswa dinilai telah mendapatkan dan menguasai berbagai kompetensi yang dibutuhkan untuk menjadi seorang 
konselor ataupun guru BK. Salah satu kompetensi tersebut adalah perilaku altruistik.

Instrumen penelitian yang digunakan untuk mengukur perilaku altruistik mahasiswa Bimbingan dan Konseling IAIN Batusangkar adalah skala likert dengan lima alternatif jawaban untuk perilaku altruistik yaitu "Sangat Sesuai (SS), Sesuai (S), Kurang Sesuai (KS), Tidak Sesuai (TS), Sangat Tidak Sesuai (STS)". Jawaban-jawaban ini akan diberi skor 5-1 untuk pernyataan positif dan skor 1-5 untuk pernyataan negatif. Data perilaku altruistik mahasiswa diperoleh dari skor jawaban mahasiswa dari instrumen yang telah diisi mahasiswa. Analisis data dilakukan dengan analisis univariat yang menghasilkan distribusi frekuensi berdasarkan persentase dari tiap-tiap karakteristik indikator yang diteliti. Analisis ini dilakukan untuk melihat tingkat perilaku altruistik mahasiswa BK. Teknik yang digunakan untuk mengetahui tingkat perilaku altruistik mahasiswa dengan klasifikasi sangat tinggi, tinggi, sedang, rendah, dan sangat rendah.

\section{HASIL}

Perilaku altruistik mahasiswa dalam penelitian mencakup enam aspek perilaku altruistik yang meliputi; (1) keinginan untuk memberi; (2) empati; (3) sukarela; (4) membantu orang lain; (5) mengutamakan orang lain; dan (6) hasilnya baik bagi yang menolong maupun yang menolong. Hasil penelitian secara umum dengan masingmasing aspeknya disajikan dalam grafik 1 sebagai berikut:

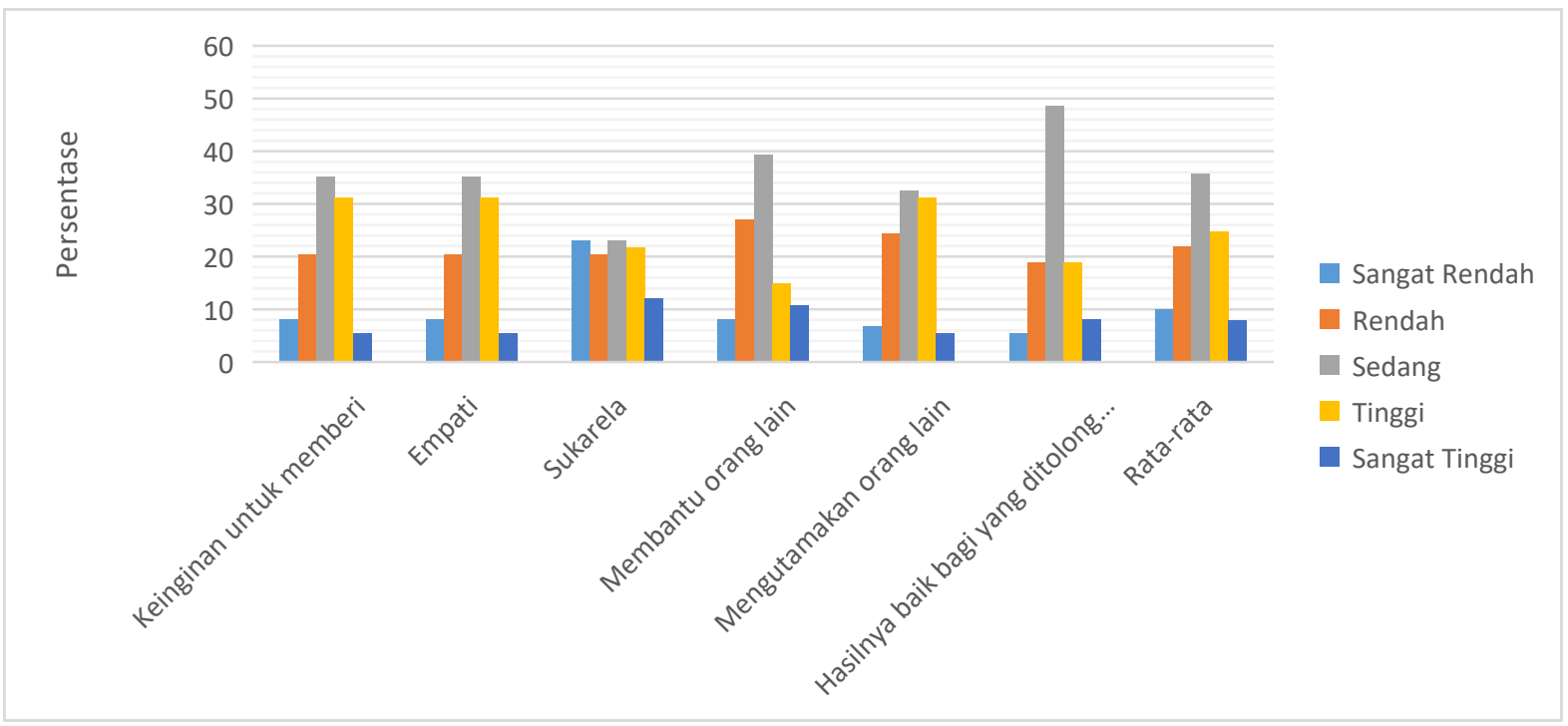

Grafik 1. Visualisasi Hasil Pengolahan Data Perilaku Altruistik Mahasiswa

Berdasarkan visualisasi data pada grafik 1 di atas dapat dilihat secara umum perilaku altruistik mahasiswa secara umum dengan rata-rata capaian $20 \%$. Apabila dilihat dari masing- masing kategori, sangat rendah $9.9 \%$, rendah $21.9 \%$, sedang $25.6 \%$, tinggi $24.8 \%$ dan sangat tinggi sebanyak $7.9 \%$. Artinya, masih sebagian kecil mahasiswa BK yang menampilkan perilaku altruistik pada kategori tinggi dan sangat tinggi. Tampilan perilaku altruistik mahasiswa BK secara rinci disajikan dalam tabel 1 sebagai berikut:

Tabel 1. Hasil Pengolahan Data Perilaku Altruistik Mahasiswa BK dalam Berbagai Aspek

\begin{tabular}{|c|c|c|c|c|c|c|c|}
\hline \multirow[b]{2}{*}{ No. } & \multirow[b]{2}{*}{ Aspek } & \multicolumn{5}{|c|}{ Klasifikasi } & \multirow[b]{2}{*}{$\%$} \\
\hline & & $\begin{array}{l}\text { Sangat } \\
\text { Rendah }\end{array}$ & Rendah & Sedang & Tinggi & $\begin{array}{l}\text { Sangat } \\
\text { Tinggi }\end{array}$ & \\
\hline 1 & Keinginan untuk memberi. & 8,1 & 20,3 & 35,1 & 31,1 & 5,4 & 100 \\
\hline 2 & Empati & 8,1 & 20,3 & 35,1 & 31,1 & 5,4 & 100 \\
\hline 3 & Sukarela & 23 & 20,3 & 23 & 21,6 & 12,1 & 100 \\
\hline 4 & Membantu orang lain & 8,1 & 27 & 39,2 & 14,9 & 10,8 & 100 \\
\hline 5 & Mengutamakan orang lain & 6,8 & 24,3 & 32,4 & 31,1 & 5,4 & 100 \\
\hline 6 & $\begin{array}{l}\text { Hasilnya baik bagi yang ditolong dan } \\
\text { menolong }\end{array}$ & 5,4 & 18,9 & 48,6 & 18,9 & 8,1 & 100 \\
\hline & Rata-rata & 9,9 & 21,9 & 35,6 & 24,8 & 7,9 & 20 \\
\hline
\end{tabular}


Data pada tabel 1 di atas menunjukkan perilaku altruistk mahasiswa BK dilihat dari berbagai aspek perilaku altruistik. Pada aspek keinginan untuk memberi diperoleh data bahwa pada kategori sangat rendah $8.1 \%$, rendah $20.3 \%$, sedang $35.1 \%$, tinggi $31.1 \%$ dan sangat tinggi $5.4 \%$. Data tersebut mengandung makna bahwa perilaku altruistik mahasiswa BK pada keinginan untuk memberi belum sesuai dengan harapan yaitu masih banyak berkisar pada kategori sedang, rendah dan sangat tendah. Pada aspek empati diperoleh data dengan klasifikasi sangat rendah $8.1 \%$, rendah $20.3 \%$, sedang $35.1 \%$, tinggi $31.1 \%$ dan sangat tinggi 5.4\%. Data tersebut artinya perilaku altruistik mahasiswa pada aspek empati dengan klasifikasi sangat tinggi sedikit sekali dan persentase yang baling banyak yaitu pada klasifikasi sedang. Pada aspek perilaku sukarela diperoleh data pada klasifikasi sangat rendah 23\%, rendah 20.3\%, sedang 23\%, tinggi $21.6 \%$, dan sangat tinggi $12.1 \%$. Data tersebut menunjukkan bahwa masih sebagian kecil mahasiswa yang memiliki perilaku sukarela pada klasifikasi tinggi dan sangat ringgi. Pada aspek membantu orang lain diperoleh data pada klasifikasi sangat rendah $8.1 \%$, rendah $27 \%$, sedang $39.2 \%$, tinggi $14.9 \%$, dan sangat tinggi $10.8 \%$. Dari data tersebut kelihatan paling banyak adalah pada klasifikasi sedang. Sementara pada klasifikasi sangat tinggi hanya sedikit sekali yaitu $10.8 \%$. Artinya, hanya sebagian kecil mahasiswa yang membantu orang lain pada klasifikasi sangat tinggi.

Pada aspek mengutamakan orang lain diperoleh data pada klasifikasi sangat rendah $6.8 \%$, rendah $24.3 \%$, sedang $32.4 \%$, tinggi $31.1 \%$, dan sangat tinggi 5.4\%. Pada aspek hasilnya baik bagi yang ditolong dan menolong diperoleh data pada klasifikasi sangat rendah $5.4 \%$, rendah $18.9 \%$, sedang $48.6 \%$, tinggi $18.9 \%$, dan sangat tinggi $8.1 \%$. Data tersebut mempunyai makna bahwa masih sebagian kecil mahasiswa yang berpandangan bahwa perilaku hasilnya baik bagi yang ditolong dan menolong.

\section{PEMBAHASAN}

Secara umum diperoleh gambaran bahwa sebagian kecil mahasiswa yang memiliki perilaku altruistik pada klasifikasi tinggi dan sangat tinggi. Hasil penelitian ini sejalan dengan penelitian yang dilakukan oleh (Yandri et al., 2019) yang mengungkapkan bahwa "rata-rata perilaku altruistik guru BK dalam melaksanakan layanan konseling individu berada pada kategori sedang". Berbeda halnya dengan hasil penelitian (Nusantara, 2016) yang mengungkapkan bahwa altruisme mahasiwa BK UNNES berada pada kategori tinggi.

Secara khusus, hasil penelitian menunjukkan bahwa rata-rata perilaku altruistik mahasiswa Bimbingan dan Konseling IAIN Batusangkar pada aspek keinginan untuk memberi (berbagi) berada pada kategori sedang. Artinya masih ada mahasiswa yang rendah keinginanya untuk mau memberi dan berbagi dengan orang lain. Setiap individu pada dasarnya berpotensi untuk berbuat kebaikan. Individu terlahir sebagai makhluk sosial memiliki kebutuhan dasar untuk meminta dan memberikan bantuan dan pertolongan kepada orang lain. Sebagai makhluk yang lemah, setiap manusia pasti membutuhkan orang lain untuk mengatasi segala kekurangan dan kelemahannya. Sebaliknya, sebagai makhluk yang sempurna dan memiliki kelebihan, setiap manusiapun memiliki kuasa dan kewajiban sosial untuk memberi bantuan, meringankan kesulitan dan beban orang lain. Adapun makna dari keinginan untuk memberi adalah adanya keinginan dan tujuan untuk memenuhi kebutuhan orang lain, mau berbagi sesuatu yang dimiliki dengan orang lain. Hal tersebut merupakan wujud dari perilaku altruistik. Perlaku altruistik didefinisikan sebagai perilaku sukarela untuk menolong orang lain yang didasarkan motivasi utama berupa kebutuhan untuk menolong orang lain dan selalu diikuti dengan respon simpati dengan ketulusan yang konsisten untuk menolong orang lain (Hanana, 2019). Maka dari itu, perilaku altruistik merupakan aspek yang fundamental bagi setiap konselor. Sekaitan dengan itu (Alam, 2016) menyatakan bahwa altruisme sebagai suatu nilai merupakan aspek fundamental dalam diri individu sebagai prasyarat untuk bergabung dengan orang lain.

Sikap dan perilaku konselor sangat menentukan keberhasilan layanan bimbingan dan konseling (Sa'idah \& Annajih, 2019). Di antara sikap dan perilaku tersebut yaitu perilaku altruistik berupa empati dan suka menolong dan berbagi. Seorang konselor tentunya diharapkan memiliki keinginan untuk berbagi sehingga dalam memberikan pelayanan akan selalu bertanggungjawab dan tidak memilih-milih dalam memberikan layanan, sehingga klien benar-benar terbantu dengan pelayanan bimbingan dan konseling. Karena secara tidak langsung bahwa sikap dan perilaku konselor merupakan objek observasi bagi klien (Makhmudah, 2017). Jika ketulusan dan perilaku altruistic berupa empati dan suka menolong itu tampak bagi klien, maka kualitas hubungan konseling akan semakin baik. Karena perilaku altruistik lahir karena dorongan dari dalam diri si penolong untuk memberi pertolongan dan berbagi dengan orang lain. Dorongan ini hadir karena keinginan untuk membantu memenuhi kebutuhan orang lain. Atas dasar itu, proses layanan konseling memerlukan perbuatan konselor yang peduli akan keadaan dan masa depan klien yang mendambakan kasih sayang dan empati, sehingga klien luput dari kealpaan, kelalaian, keras kepala, dan reaksi negatif lainnya (Ardimen, 2018a).

Selanjutnya perilaku altruistik pada aspek empati juga berada pada kategori sedang. Berdasarkan data tersebut dapat diketahui masih ada di antara mahasiswa BK yang memiliki sikap empati yang rendah. Empati 
merupakan salah satu kemampuan dasar yang harus dimiliki bagi seorang guru BK/ konselor dalam melaksanakan pelayanan konseling. Layanan konseling akan berjalan dengan baik jika konselor memiliki sikap empati. Empati yang dalam dapat dirasakan baik oleh klien maupun konselor. Hal ini sejalan dengan pendapat Geldard \& Geldard (Yandri et al., 2019) "Seorang guru BK/ konselor harus memiliki kepribadian yang efektif dan matang dengan menunjukkan sikap yang tulus, berempati, hangat, dilandasi kasih sayang, penerimaan yang positif tanpa syarat, menunjukkan perhatian, pengertian dan dukungan, serta bersikap kerjasama yag baik dengan orang lain dengan memberikan penghargaan yang tinggi terhadap orang lain”.

Sikap empati ditampilkan oleh individu yang senang menolong orang lain dan memeiliki empati yang tinggi bila dibandingkan dengan indivitdu yang tidak menolong orang lain (M. N. Putri \& Suryanto, 2018). Di samping itu, empati dapat menimbulkan motivasi bagi konselor dalam menolong orang lain/ klien. Empati memiliki korelasi yang sangat erat dengan perilaku pro-sosial (Latifah \& Susanti, 2016). Sebaliknya konselor yang tidak memiliki empati maka akan mengalami kesulitan dalam membantu klien dalam hubungan konseling. Penelitian yang dilakukan oleh Pujiyanti (dalam Yandri \& Juliawati, 2019) mengungkapkan adanya kontribusi empati secara signifikan terhadap perilaku altruistik siswa siswi, dan empati memberi kontribusi terhadap altruisme di samping faktor suasana hati, menyakini keadilan dunia dan faktor sosiologis. Berdasarkan hal tersebut, maka sangat penting bagi mahasiswa jurusan BK sebagai calon guru BK/ Konselor untuk bisa memiliki sikap empati dari sejak dini.

Selanjutnya perilaku altruistik mahasiswa jurusan BK dilihat pada aspek sukarela berada pada kategori sangat rendah. Adapun yang dimaksud dengan sukarela di sini adalah memberikan bantuan dan pertolongan kepada orang lain tanpa paksaan dan tidak mengharapkan imbalan dari orang yang ditolongnya. Artinya apa yang akan diberikan itu semata-mata hanya untuk orang lain, tidak ada niat untuk mengharapkan imbalan/ pamrih dari orang yang dibantu. Jika dilihat dari hasil angket yang disebarkan ke mahasiswa terlihat masih banyak mahsiswa yang cenderung menimbang-nimbang atau memikirkan dampak terlebih dahulu sebelum bertindak untuk membantu dan menolong orang lain. Dalam memberikan pertolongan masih memperhatikan faktor hubungan kekerabatan/ kedekatan dan mengharapkan sesuatu balasan dari orang yang ditolong, seperti ingin mendapatkan pujian atau sekedar menacari perhatian dari orang yang ditolong. Seharusnya individu yang berperilaku altruistik dalam memberikan pertolongan hendaknya selalu diniatkan ikhlas tanpa paksaan dan mengahrapkan balasan dari orang lain.

Efek dari keikhlasan dan kesukarelaan ini hanya kepuasan diri di penolong karena telah mampu memberi arti kepada orang lain. Melihat orang yang dibantu selamat dan berbahagia merupakan kesenangan bathin yang tidak ternilai harganya. Jadi bagi pelaku altruistik, kebahagiaan orang lain karena bantuan yang diberikan adalah sumber kebahagiaannya. Perilaku altruistik mahasiswa BK pada aspek membantu orang lain berda pada kategori sedang yaitu sebanyak 29 orang atau sebesar 39,2\%.. Artinya masih ada diantara mahasiswa dalam membantu orang lain itu didorong oleh faktor sebab akibat. Dari angket yang disebarkan, ada di antaranya mahasiswa hanya akan membantu jika diminta, kemudian membantu orang-orang yang dikenalinya saja. Ketika orang tersebut pernah menyakitinya maka ia akan berfikir untuk mau membantu orang tersebut. Oang-orang yang suka mambantu orang yang mengalami kesusahan dan kesulitan maka akan memberikan perasaan positif dalam dirinya, seperti adanya pearasaan bahagia, senang dan selalu berfikir positif terhadap situasi yang terjadi. Dalam hal ini, hasil penelitian (Pamungkas \& Muslikah, 2019) menunjukkan bahwa mereka yang suka menolong mempunyai empati lebih tinggi daripada mereka yang tidak menolong. Orang yang paling altruistik menggambarkan diri mereka sebagai bertanggung jawab, bersosialisasi, menenangkan, dan memunyai sikap toleran.

Selanjutnya perilaku altruistik mahasiswa pada indikator mengutamakan kepentingan orang lain berada pada kategori sedang. Dari hasil tersebut dapat diketahui bahwasanya masih ada mahasiswa yang lebih mendahulukan kepentingan dirinya sendiri daripada kepentingan orang lain. Perilaku altruistik mengutamakan kepentingan orang lain dapat diartikan ketika ada orang lain membutuhkan bantuan, maka seorang altruis akan segera menolong meski ia sebenarnya sedang memiliki urusan dan kepentingan lain. Perilaku altruistik akan mendahulukan dan memprioritaskan kepentingan orang yang dibantu dan mengenyampingkan kepentingan diri sendiri. Hal ini menyiratkan bahwa perilaku altruistik tidak ditujukan untuk diri sendiri melainkan ditujukan untuk orang lain. Kemudian perilaku altruistik pada indikator hasilnya baik bagi yang menolong maupun yang ditolong berada pada kategori sedang. Artinya masih ada ditemukan mahasiswa yang dalam menolong orang lain tersebut tidak memikirkan akibat atau dampaknya. Seharusnya bantuan yang diberikan itu sesuai dengan kebutuhan yang ditolong, sehingga pertolongan yang diberikan diharapkan mampu memberikan manfaat dan hasil yang positif untuk keduanya. Perilaku altruistik akan menghasilkan efek yang baik bagi kedua belah pihak. Orang yang ditolong akan diuntungkan karena pertolongan yang didapatkannya. Sesuatu yang semula terasa berat akan menjadi ringan berkat bantuan yang diterimanya. Sedangkan orang yang menolong akan mendapatkan kepuasan tersendiri (internal reward) yang bisa saja berwujud perasaan berharga, bahagia dan nyaman karena telah mampu memberi dan berbagi kepada orang lain. 
Menurut Yunico, Lukmawati, \& Botty, (2016: 183) altruistik juga dapat dipahami sebagai perhatian yang bersifat suka/senang untuk mempeduli kepentingan orang lain, lawan dari egoisme. Perilaku altruistik merupakan perilaku prososial yang dimuliakan dalam Islam. Karena Islam hadir untuk kesejahteraan alam semesta. Sejalan dengan itu, Rious (Rahmawati, 2017) menyatakan bahwa altruisme dapat digolongkah pada tingkah laku prososial, yaitu tingkah laku yang bertujuan menolong orang lain baik individu maupun kelompok secara sukarela. Sebagai sesuatu yang penting tentunya perilaku altruistik bisa dilakukan oleh siapapun dan kapanpun juga. Perilaku ini harus didasari keimanan dan keikhlasan, dan bukan sekedar karena faktor personal atau interpersonal semata. Hal ini tergambar dalam (QS.Al-Imron (3):134) yang artinya: "Orang-orang yang menafkahkan (hartanya), baik di waktu lapang maupun sempit, dan orang-orang yang menahan amarahnya dan memaafkan (kesalahan) orang. Allah menyukai orang-orang yang berbuat kebajikan."

Dalam agama Islam, perilaku menolong merupakan perilaku yang sangat mulia dan sangat dihargai, sehingga setiap muslim wajib melakukannya. Tolong menolong merupakan kecenderungan alamiah sebagai manusia. Sebagai makhluk sosial tentunya setiap individu pasti tidak bisa lepas dari orang lain dan lingkungannya, setiap manusia akan membutuhkan manusia lainnya. Dengan demikian, secara aspek sosial dan spritual perlaku tolong menolong sangat disukai dan dianjurkan bagi setiap individu. Konselor sebagai tenaga profesional dituntut untuk senantiasa peduli terhadap manusia umumnya dan khususnya terhadap klien. Sebagaimana Allah Berfirman dalam QS. Al Maidah (5:2) yang artinya: ... dan tolong-menolonglah kamu dalam (mengerjakan) kebajikan dan takwa, dan jangan tolong menolong dalam berbuat dosa dan pelanggaran. Dan bertakwalah kamu kepada Allah, sesungguhnya Allah amat berat siksa-Nya. (QS. Al Maidah: 2). Dari penjelasan ayat tersebut jelas bahwasanya Islam mengajarkan setiap muslim untuk saling tolong menolong dalam kebaikan, dapat memberikan manfaat yang baik bagi orang lain, meringankan beban orang lain, memberikan bantuan kepada mereka yang mengalami kesulitan tanpa mengharapkan adanya imbalan atas perbuatan yang dilakukannya. Sebaik-baiknya manusia adalah yang bisa memberikan manfaat untuk orang lain.

Kemudian juga dijelaskan dalam (QS Al-Baqarah (2): 25) "Orang yang melakukan perilaku menolong dihargai dan akan dihadiahi dengan surga nanti di hari pembalasan." Dengan demikian diketahui bahwa Allah sangat menyukai orang-orang yang gemar meringankan beban dan kesulitan orang lain, bahkan Allah menjanjikan surga bagi yang suka menolong orang lain di hari pembalasan nantinya. Bahkan Allah berjanji akan meringankan penderitaan seseorang di dunia dan di akhirat jika mereka bisa meringankan penderitaan orang lain. Hal ini sesuai dengan hadist Nabi SAW yang berbunyi: "Barang siapa melapangkan seorang mukmin dari suatu kesusahan dunia, Allah akan melapangkannya dari salah satu kesusahan di hari kiamat. Barang siapa meringankan penderitaan seseorang, Allah akan meringankan penderitaanya di dunia dan akhirat. Barang siapa menutupi (aib) seorang Muslim, Allah akan menutupi (aib)nya di dunia dan akhirat. Allah akan menolong seorang hamba selama hamba itu mau menolong saudaranya” (HR. Muslim dari Abu Hurairah).

(Rahman, 2017) mengatakan dalam Islam nilai-nilai perilaku menolong itu ditentukan oleh beberapa hal sebagai berikut: a). Perilaku menolong harus dilakukan dengan penuh keikhlasan, yaitu motif hanya untuk mengharap ridha Allah Swt; b). Kualitas perilaku menolong ditentukan oleh sejauh mana perilaku tersebut beresiko (QS. Al-Imran (3): 92). Semakin tinggi risiko yang akan ditanggung, semakin tinggi kualitas perilaku menolongnya; c). Kualitas perilaku menolong dipengaruhi oleh caranya perilaku menolong itu ditunjukkan; d). Kualitas perilaku menolong akan lebih tinggi apabila perilaku menolong itu disembunyikan sehingga tidak ada seoranpun tahu. Dengan demikian dapat disimpulkan bahwa mengutamakan orang lain daripada diri sendiri akan menjadi prasyarat untuk mendapatkan sebuah kebaikan. Orang yang suka membantu orang lain mempunyai posisi yang penting dan mulia di sisi Allah SWT.

Selanjutnya, konselor (helper) sebagai pelaku utama dalam pelaksanaan konseling, dituntut untuk memiliki sifat membantu yang karakteristiknya tidak sama dengan sifat membantu biasa. Urgensi bimbingan dan konseling sebagai sebuah hubungan yang bersifat membantu membutuhkan seorang konselor yang memiliki perilaku altruistik yang baik. Jika konselor tidak memiliki perilaku altruistik maka ia akan kesulitan dalam membangun hubungan membantu dengan klien saat proses konseling berlangsung, karena kualitas hubungan dalam konseling sangat ditentukan oleh kualitas pribadi konselor. (Makhmudah, 2017) menyatakan bahwa individu dapat dikategorikan memiliki kepribadian yang baik, ketika ia mampu berinteraksi dan menyatu dengan lingkungannya. Demikian pula dengan konselor, seorang konselor dapat dikategorikan sebagai konselor yang profesional apabila ia telah mampu berinteraksi dan menyatu dengan baik sebagai seorang konselor.

Oleh sebab itu, dapat dikatakan bahwa seorang konselor "wajib" memiliki sifat, sikap dan tingkah laku altruistik. Kewajiban ini juga berlaku untuk orang-orang yang sedang mempersiapkan diri menjadi seorang konselor, yaitu mahasiswa Bimbingan dan Konseling (BK) mengingat perilaku altruistik bukanlah perilaku "sim salabim" yang langsung ada tanpa kemauan yang dibiasakan dan terus dilatihkan. Di antara contoh kasus, hasil penelitian (Yandri et al., 2019) menunjukkan bahwa sebagian guru BK belum menunjukkan perilaku altruistic terkait dengan aspek empati, beliaef on a just word, dan kepekaan sosial. Maka dari itu, diharapkan konselor sekolah agar lebih aktif mengikuti kegiatan-kegiatan yang menunjang terwujudnya perilaku altruisme konselor 
sekolah yang profesional dengan mengikuti berbagai seminar. Sejalan dengan itu (Ardimen, 2018b) menegaskan bahwa pengetahuan, keterampilan dan kepribadian serta cara pandang konselor sekolah semestinya selalu diupdate setiap saat sehingga konselor sekolah mampu menjawab tantangan perubahan.

Untuk menindaklanjuti hasil tentang perilaku altruistik mahasiswa Bimbingan dan Konseling IAIN Batusangkar, ada beberapa hal yang dapat dilakukan dalan bentuk upaya pengembangan perilaku altruistik mahasiswa, yaitu sebagai berikut:

1. Melalui kurikulum dan Kegiatan Pembelajaran

Ada beberapa mata kuliah pada jurusan bimbingan dan konseling yang ada kaitannya dalam pembentukan perilaku altruistik, seperti; Psikologi Sosial, Komunikasi Antar Pribadi, Dasar-Dasar Bimbingan dan Konseling, Layanan BKp dan KKp, Teknik Laboratorium Konseling, Model-Model Konseling, Konseling Individual, Psikologi Konseling, dan Profesionalisasi BK. Semua mata kuliah tersebut dipersiapkan untuk mahasiswa agar mereka memiliki kompetensi pada bidang bimbingan dan konseling. Semakin tinggi tingkat perkuliahan mereka seharusnya mahasiswa tersebut semakin memahami akan nilai-nilai yang terkandung dalam bimbingan dan konseling, seperti sikap altruistik, karena perilaku altruistik itu sendiri bisa disebabkan karena proses pembelajaran. Hal ini sejalan dengan pendapat Berns (Nusantara, 2016) bahwa "sifat altruistik juga bisa ditumbuhkan melalui pola asuh di rumah dan pendidikan di sekolah”.

Sebagai calon konselor tentunya mahasiswa diharapkan mampu menerapkan dan menjiwai sikap altruistik pada diri mereka. Namun pada kenyataannya masih ada terlihat dari sikap-sikap yang dimunculkan oleh mahasiswa ketika proses pembelajaran yang masih jauh dari perilaku altruistik, seperti: tidak peduli dengan kondisi dan situasi yang terjadi di kelas, tidak peka dan empati terhadap permasalahan yang dialami oleh temannya, tidak mau menyumbang dan lain sebagaimya. Sedangkan dosen diharapakan tidak hanya mengajarkan materi keilmuan saja, tetapi juga diharapkan menginternalisasikan dan mengembangkan kepribadian yang positif serta menerapkan sikap-sikap altruistik dalam hubungannya dengan orang lain, menciptakan susasana pembelajaran yang saling peduli satu dengan yang lainnya. Di samping itu dosen juga diharapkan bisa menjadi contoh dan teladan bagi mahasiswa dalam menerapkan perilaku altruistik, menunjukkan sikap-sikap yang mengarah kepada perilaku altruistik, seperti; tidak segan membantu mahasiswa yang mengalami kesulitan, melayani mahasiswa yang membutuhkan bantuan, dan lain sebagianya. Perbuatan baik pasti akan dibalas dengan kebaikan pula. Artinya, perilaku altruistik dapat dibentuk melalui keteladanan atau percontohan yang dilakukan oleh Dosen kepada mahasiswa melalui sikap-sikap yang ditampilkan sehari-hari, dan melalui pengajaran secara langsung kepada orang lain, khusunya mahasiwa jurusan BK. Di samping itu, perilaku altruistik juga dapat dibentuk dan dikembangkan melalui layanan bimbingan dan konseling. Hal tersebut dibuktikan oleh temuan penelitian (Mesa et al., 2020) yang menunjukkan bahwa layanan bimbingan kelompok efektif dalam mengembangkan perilaku altruistik siswa.

2. Melalui Kegiatan Kemahasiswaan

Di samping melalui kegiatan pembelajaran, sikap altruistik juga bisa dikembangkan melalui kegiatan kemahasiswaan. Kegiatan kemahasiswaan jurusan Bimibngan dan Konseling seharusnya lebih banyak berorientasi pada kegiatan sosial agar mahasiswa mampu meningkatkan dan mengembangkan nilai-nilai altruistik yang sudah ada pada dirinya. Selama ini sudah ada beberapa kegiatan sosial yang dilakukan mahasiswa, namun masih perlu dievaluasi lagi teknis pelaksanaannya. Kemudian kegiatan Himpunan Mahasiswa Jurusan BK juga diharapkan mampu menjalin kerjasama dengan Unit Kegiatan Mahasiswa lainnya yang ada gerakan sosialnya, seperti PMI, PIK-M, Pramuka, dan lainya.

Dalam rangka menumbuh-kembangkan karakter konselor profesional dibutuhkan tiga proses berkelanjutan, yaitu: (1) menggali nilai-nilai karakter konselor profesional yang dibutuhkan, (2) implementasi tradisi nilai ke dalam proses pembelajaran, dan (3) evaluasi nilai-nilai yang berkembang selama ini.. Selanjutnya, para konselor perlu melakukan inovasi dan pengembangan proses konseling yang lebih efektif untuk mencapai tujuan layanan yang diharapkan (Ardimen, 2017). Di samping itu, untuk meningkatkan dan pengembangan kompetensi kepribadian calon konselor, maka perlu disusun program pelatihan. Program pelatihan merupakan kegiatan yang sistemik, yaitu rencana kegiatan yang memiliki dasar, tujuan, komponen, materi, metode, proses, media, dan perangkat pendukung lainnya untuk pencapaian tujuan program. Program pelatihan dimaksud dalam upaya pengembangan kepribadian calon konselor yang dirancang secara sistematis dan terprogram. Di antara komponen program pelatihan yang ditawarkan adalah; (1) dasar filosofis dan ilmiah perlunya pelatihan, (2) tahapan pelatihan, (3) format pelatihan, (4) materi pelatihan, (5) tugas pendidik konselor dan calon konselor dalam pelatihan, (6) evaluasi program pelatihan. 


\section{SIMPULAN DAN SARAN}

Beberapa kesimpulan dapat disarikan dari penelitian ini di antaranya adalah. Perilaku altruistik merupakan salah satu dimensi kepribadian mahasiswa yang sangat berarti dalam kehidupannya, terutama bagi dirinya sebagai calon konselor dan bagi konselor dalam membina hubungan konseling yang harmonis, dinamis sehingga menjadi efektif. Hasil penelitian ini menunjukkan masih sebagian kecil mahasiswa yang memiliki perilaku altruistic pada klasifikasi tinggi dan sangat tinggi. Begitu juga pada aspek-aspek perilaku altruistic yang diteliti, baik pada aspek keinginan untuk memberi, empati, sukarela, membantu orang lain, mengutamakan orang lain, dan meresa hasilnya baik bagi yang ditolong dan menolong. Idealnya tentu sikap dan perilaku ini terus dibina dan dikembangkan pada setiap mahasiswa sehingga semua mahasiswa memiliki sikap dan perilaku altruistic yang berkualitas sangat tinggi.

Upaya pengembangan perilaku altruistik mahasiswa BK dapat dilakukan melalui kurikulum dan kegiatan proses pembelajaran, kegiatan kemahasiswaan dan program pelatihan secara terencana. Semakin banyak pengetahuan dan pengalaman mahasiswa diharapakan akan semakin memahami nilai-nilai yang terkandung dalam bimbingan dan konseling, serta semakin mantap kepribadiannya terutama dalam bentuk perilaku altruistik.

\section{DAFTAR RUJUKAN}

Alam, M. (2016). Altruisme Semu di Sekolah: Analisis terhadap Praktek-praktek Kekerasan dan Keterlibatan School Stakeholder dalam Kegiatan Inisiasi Sekolah. Jurnal Sosiologi Reflektif, 10(1), 1-16.

Ardimen, A. (2017). Evaluasi Kinerja Konselor dalam Proses Konseling dan Riset Konseling di Sekolah. JURNAL EDUKASI: Jurnal Bimbingan Konseling, 3(1), 58-73.

Ardimen, A. (2018a). Pengembangan Kepribadian Konselor Berbasis Asmaul Husna dalam Pelayanan Konseling. Hisbah: Jurnal Bimbingan Konseling Dan Dakwah Islam, 15(2), 102-115.

Ardimen, A. (2018b). Visi Baru Konselor Sekolah dalam Rangka Meningkatkan Kualitas Layanan Pendidikan di Sekolah dan Madrasah. JKI (Jurnal Konseling Indonesia), 4(1), 22-29.

Diyai, I., Bidjuni, H., \& Onibala, F. (2019). Hubungan Kecerdasan Spiritual dengan Perilaku Altruistik pada Mahasiswa Keperawatan Universitas Sam Ratulangi Manado. Jurnal Keperawatan, 7(1), 1-6.

Hanana, N. F. (2019). Pengaruh Self-Esteem dan Kecerdasan Emosi Terhadap Perilaku Prososial. Tazkiya: Journal of Psychology, 6(1), 85-100.

Latifah, L., \& Susanti, R. H. (2016). Upaya Meningkatkan Empati Siswa SMP Muhammadiyah 1 Malang Melalui Penggunaan Teknik Sinema Terapi. JKI (Jurnal Konseling Indonesia), 1(2), 88-95.

Makhmudah, U. (2017). Mempersiapkan Kompetensi Kepribadian Calon Konselor untuk Menghadapi Masyarakat Ekonomi ASEAN (MEA). Jurnal Psikoedukasi Dan Konseling, 1(1), 68-76.

Mesa, N. M. R., Aspin, A., \& Rudin, A. (2020). Pengaruh Layanan Bimbingan Kelompok terhadap Perilaku Altruisme Siswa. Jurnal Ilmiah Bening (Belajar Bimbingan Dan Konseling), 4(1), 35-44.

Ni'mah, R. (2017). Hubungan Empati dengan Perilaku Altruistik. At-Tuhfah, 6(1), 99-115.

Nusantara, B. A. (2016). Tingkat Altruisme Mahasiswa Bimbingan dan Konseling Fakultas Ilmu Pendidikan Universitas Negeri Semarang (Studi Angkatan 2013, 2014, dan 2015). Skripsi. Jurusan Bimbingan dan Konseling Universitas Negeri Semarang. Semarang.

Pamungkas, I. M., \& Muslikah, M. (2019). Hubungan Antara Kecerdasan Emosi dan Empati dengan Altruisme pada Siswa Kelas XI MIPA SMA N 3 Demak. JURNAL EDUKASI: Jurnal Bimbingan Konseling, 5(2), 154-167.

Pane, R. M. (2016). Kompetensi Kepribadian Konselor dalam Pelaksanaan Bimbingan dan Konseling Islam. Hikmah, 10(2), 1-15.

Putri, A. (2016). Pentingnya Kualitas Pribadi Konselor dalam Konseling untuk Membangun Hubungan Antar Konselor dan Konseli. Jurnal Bimbingan Konseling Indonesia, 1(1), 10-13.

Putri, M. N., \& Suryanto. (2018). Hubungan Antara Perilaku Altruisme dengan Partisipasi Sosial pada Anggota Karang Taruna dengan Rasa Kepemilikan Organisasi (Sense of Belonging) Sebagai Variabel Intervening. Jurnal Psikologi Kepribadian Dan Sosial, 7, 1-12.

Rahman, A. A. (2017). Psikologi Sosial: Integrasi Pengetahuan Wahyu dan Pengetahuan Empirik. Jakarta: Rajawali Pers.

Rahmawati, S. W. (2017). Peran Pengasuhan Holistik Terhadap Altruisme dan Bullying. Humanitas: Jurnal Psikologi Indonesia, 14(1), 10-25.

Sa'idah, I., \& Annajih, M. Z. H. (2019). Perspektif Nilai Pesantren: Pengembangan Kualitas Pribadi Ideal Konselor. Ulumuna: Jurnal Studi Keislaman, 5(1), 1-12.

Yandri, H., Fikri, M. K., \& Juliawati, D. (2019). Penerapan Perilaku Altruistik dalam Layanan Konseling Individu Oleh Guru Bimbingan dan Konseling di Sekolah. Tarbawi: Jurnal Ilmu Pendidikan, 15(1), 53-64. 